\title{
Resolusi Konflik dan Kepuasan Pernikahan: Analisis Perbandingan Berdasarkan Aspek Demografi
}

\author{
Abdul Muhid ${ }^{(1)}$, Prayinda Elsa Nurmamita ${ }^{(1)}$, Lailatul Muarofah Hanim ${ }^{(3)}$ \\ abdulmuhid@uinsby.ac.id \\ ${ }^{(1)}$ Fakultas Psikologi dan Kesehatan, Universitas Islam Negeri Sunan Ampel, Surabaya, Indonesia \\ ${ }^{(2)}$ Program Studi Psikologi, Universitas Trunojoyo Madura, Bangkalan, Indonesia
}

\begin{abstract}
The purpose of this study is to examine the effect of conflict resolution on marital satisfaction and examine differences in conflict resolution and marital satisfaction in terms of demographic aspects including ethnic background, level of education, occupation, number of children, length of marriage, ownership status of residence, and shared residence. The subject of this study was a married couple who lived in the northern city of Surabaya with a sample of 150 people. Data collection is done using research instruments, namely the Conflict Resolution Scale to measure conflict resolution, and ENRICH Marital Satisfaction Scale used to measure marital satisfaction. Statistical analysis techniques used were descriptive statistical analysis, analysis of regression (ANAREG), and analysis of variances (ANOVA). The results showed $R=0.659, R$ Square $=0.434 ; F=113.399 ; t=10.649$ ( $p=0.000$ $p<0.05)$ it shows a significant influence between conflict resolution on marital satisfaction. Based on the comparison analysis shows there are significant differences in conflict resolution and marital satisfaction in terms of demographic aspects including ethnic background, level of education, occupation, number of children, length of marriage, ownership status of residence, and shared residence.
\end{abstract}

Keywords: conflict resolution; marital satisfaction; demographic aspects

Tujuan penelitian ini menguji pengaruh resolusi konflik terhadap kepuasan pernikahan dan menguji perbedaan resolusi konflik dan kepuasan pernikahan ditinjau dari aspek demografi meliputi latar belakang etnis, tingkat pendidikan, pekerjaan, jumlah anak, lama pernikahan, status kepemilikan tempat tinggal, dan tempat tinggal bersama. Subjek penelitian ini adalah pasangan suami istri yang tinggal di Kota Surabaya bagian Utara dengan jumlah sampel 150 orang. Pengumpulan data dilakukan menggunakan instrumen penelitian yaitu Skala Resolusi Konflik untuk mengukur resolusi konflik dan ENRICH Marital Satisfaction Scale digunakan untuk mengukur kepuasan pernikahan. Teknik analisis statistik yang digunakan yaitu analisis statistik deskriptif, analisis regresi (ANAREG) dan analisis varian (ANOVA). Hasil penelitian menunjukkan harga $\mathrm{R}=0.659$, $\mathrm{R}$ Square $=0.434$; harga $\mathrm{F}=113,399$; harga $\mathrm{t}=10.649$ $(\mathrm{p}=0.000 \mathrm{p}<0.05)$. Hal itu menunjukkan adanya pengaruh yang signifikan antara resolusi konflik terhadap kepuasan pernikahan. Berdasarkan analisis perbandingan menunjukan ada perbedaan yang siginikan resolusi konflik dan kepuasan pernikahan ditinjau dari aspek demografi meliputi latar belakang etnis, tingkat pendidikan, pekerjaan, jumlah anak, lama pernikahan, status kepemilikan tempat tinggal, dan tempat tinggal bersama.

Kata kunci: resolusi konflik; kepuasan pernikahan; aspek demografi

Received: October 29, 2018 Accepted: January 24, 2019

How to cite: Muhid, A., Nurmamita, P. E., \& Hanim, L. M. (2019). Resolusi Konflik dan Kepuasan Pernikahan: Analisis Perbandingan Berdasarkan Aspek Demografi. MEDIAPSI, 5(1), 49-61. doi:

https://doi.org/10.21776/ub.mps.2019.005.01.5

\section{Pendahuluan}

Sesuai tujuan pernikahan, setiap orang yang menikah mengharapkan adanya kesejahteraan, dan kepuasan dalam pernikahannya namun setiap ikatan pernikahan kadangkala diwarnai oleh konflik (Handayani \& Harsanti, 2017). Setiap pasangan harus mampu menyelesaikan konflik agar 
kebahagiaan dalam rumah tangganya tercapai. Akan tetapi tidak semua pasangan dapat menyelesaikan masalah rumah tangganya dengan cara yang bijak. Ketidakcakapan pasangan dalam menghadapi konflik dalam pernikahannya sering kali berujung pada perceraian.

Berdasarkan data dari Badan Pusat Statistik tahun 2016, tercatat sebesar $2.58 \%$ penduduk wanita dan $1.29 \%$ penduduk pria bercerai (Badan Pusat Statistik, 2016). Di Surabaya, dalam setahun terdapat 4938 pasangan suami isteri yang memutuskan untuk cerai berdasarkan data Pengadilan Tinggi Agama Surabaya yang dihimpun selama 2016. Surabaya menduduki peringkat keempat di Jawa Timur yang memiliki angka perceraian terbanyak (Jawa Pos, 1 Agustus 2017). Berdasarkan data di Badan Pengadilan Agama (Badilag) Mahkamah Agung RI, Provinsi Jawa Timur berada di urutan pertama kasus perceraian yaitu mencapai 87 ribu angka perceraian, sedangkan dilihat dari berkas kasus perceraian, posisi tertinggi ada di Pengadilan Tinggi Surabaya yang telah menangani 509 ribu kasus perceraian (Nurilah, 2016). Hal tersebut menunjukkan bahwa Provinsi Jawa Timur, khususnya Kota Surabaya memiliki tingkat perceraian yang cukup tinggi.

Pada dasarnya setiap pasangan tidak pernah berharap adanya perceraian, namun ketika para pasangan tidak dapat mencapai pemecahan masalah (resolusi konflik) maka perceraian menjadi jalan keluarnya (Dariyo, 2004). Menurut Hurlock (2002), perceraian merupakan akibat dari ketidakpuasan pernikahan yang buruk. Hal tersebut terjadi bila suami dan istri sudah tidak mampu lagi saling memuaskan, saling melayani dan mencari cara penyelesaian masalah yang dapat memuaskan kedua belah pihak. Hasil penelitian Goei (2017) menunjukkan bahwa meningkatnya angka perceraian diakibatkan oleh kepuasan pernikahan yang menurun.

Menurut Olson dan DeFrain (2006), kepuasan pernikahan adalah perasaan yang bersifat subjektif dari pasangan suami istri mengenai perasaan bahagia, puas, dan menyenangkan dalam perkawinannya. Sedangkan menurut Sadarjoen (2005), kepuasan pernikahan dapat tercapai jika pasangan mampu memenuhi kebutuhan masing-masing dan kebebasan dari hubungan yang mereka ciptakan serta memenuhi harapan-harapan yang mereka bawa sebelum pernikahan. Adapun McDaniel (2000) mengartikan kepuasan pernikahan sebagai kebahagiaan dalam pernikahan. Kebahagiaan bagi pasangan yang menikah, berarti mencapai sesuatu yang baik sesuai kebutuhan pasangan, keinginan, harapan, kecocokan yang unik dan tak tergantikan.

Penelitian-penelitian terdahulu terkait dengan kepuasan pernikahan antara lain dipengaruhi oleh tingkat religiusitas (Orathinkal \& Vansteenwegen, 2006; Istiqomah \& Mukhlis, 2015), keterbukaan diri (Rini \& Retnaningsih, 2008), dukungan keluarga (Prasetyo \& Rahmasari, 2016), saling perhatian (Burpee \& Langer, 2005), rasa bersykur dan pemaafan (Herawati \& Farradinna, 2017), kerendah hatian dan pola komunikasi (Estephan, 2007), dan stres konflik peran ganda (Dewi \& Saman, 2018).

$$
\text { Penelitian Handayani }
$$
menunjukkan bahwa pasangan suami-istri yang memiliki komitmen tinggi dan mampu mengatasi masalah dengan baik (resolusi konflik) berpengaruh secara signifikan terhadap kepuasan pernikahan. Sedangkan menurut Sakuei (2014) kepuasan pernikahan sangat dipengaruhi oleh bagaimana pasangan 
menyelesaikan permasalahan rumah tangganya. Adapun Fower dan Olson (1993) mengungkapkan komponen-komponen yang mempengaruhi kepuasan pernikahan, yakni komunikasi, waktu luang, orientasi keagamaan, strategi menangani konflik, manajemen ekonomi, orientasi seksual, hubungan dengan keluarga dan teman, anak dan pengasuhan, isu kepribadian, dan kesetaraan peran.

Penelitian-penelitian sebelumnya menunjukkan bahwa faktor-faktor yang mempengaruhi kepuasan pernikahan antara lain misalnya kualitas hubungan dengan keluarga (Surya, 2013), cara pasangan berkomunikasi, membuat keputusan, mengatasi konflik rumah tangga, penghasilan sebelum menikah, tingkat pendidikan, saling mengenal satu sama lain sebelum menikah, dan lama pernikahan (Papalia, Old, \& Feldman, 2008), hubungan interpersonal dengan pasangan, partisipasi keagamaan dan kehidupan seksual (Srisusanti \& Zulkaida, 2013), fleksibilitas pasangan dalam kepemimpinan rumah tangga, disiplin, negoisasi, peran dan tanggung jawab, dan peraturan rumah tangga (Sawitri \& Kurniawan, 2009), persepsi humor pasangan (Ziv \& Gadish, 1989), kondisi dinamika kelurga seperti persamaan persepsi pasangan, keterampilan komunikasi dan resolusi konflik, kepercayaan antar pasangan, dan waktu yang dihabiskan membangun hubungan bersama keluarga (Giblin, 1994), dan kemampuan menyelesaikan konflik rumah tangga (Kaur \& Sokhey, 2010; Kurdek, 1995).

Hasil penelitian Marchand dan Hock (2000) menunjukkan bahwa strategi resolusi konflik dan gejala dipresi sangat mempengaruhi terhadap kepuasan pernikahan. Sedangkan penelitian Munoz (2011) membuktikan bahwa resolusi konflik sangat efektif meningkatkan kepuasan pernikahan. Pasangan yang menganggap resolusi efektif terhadap penurunan konflik pasangan, mereka memiliki tingkat kepuasan pernikahan yang tinggi. Adapun penelitian Hanzal \& Segrin (2009) menunjukkan bahwa peran gaya resolusi konflik berpengaruh secara efektif terhadap penurunan kerentanan hubungan pasangan dan peningkatan kualitas pernikahan. Proses komunikasi yang efektif antar pasangan berdampak pada hubungan pernikahan yang semakin harmonis.

Menurut McDaniel (2000) bahwa seberapa baik pasangan menangani stressor dan menyelesaikan konflik dapat membangun lamanya masa hubungan pernikahan yang kemudian mempengaruhi kepuasan pernikahan. Sedangkan menurut Strong dan Cohen (2011) bahwa cara pasangan menyelesaikan konflik dalam pernikahan merupakan salah satu faktor yang paling penting dalam menentukan kepuasan pernikahan. Adapun temuan penelitian Utami dan Mariyati (2015) menunjukkan bahwa ada hubungan positif antara persepsi terhadap resolusi konflik suami dengan kepuasan pernikahan pada istri yang bekerja.

Selain itu, penelitian Sudarto (2014) menunjukkan bahwa kondisi dan masalah ekonomi keluarga, kesehatan, emosional, dan sosial, jumlah anak, tempat tinggal, usia perkawinan, pendapatan keluarga, alasan perkawinan, usia perkawinan, fisik pasangan, dan tingkat pendidikan turut mempengaruhi kepuasan pernikahan. Permasalahan dan kepuasan pernikahan dapat dipengaruhi oleh status pekerjaan, pendapatan, tempat tinggal dan usia perkawinan (Rumondor, 2013; Rumondor, Paramita, Francis, \& Geni, 2013). Hal itu menunjukkan bahwa ada beberapa 
aspek demografi dapat mempengaruhi resolusi konflik dan kepuasan pernikahan. Hasil penelitian Ragoan, Untoro, \& Ari (2017) menunjukkan bahwa faktor ekonomi dan perbedaan etnis juga mempengaruhi kepuasan pernikahan. Perbedaan budaya dan etnis mempengaruhi cara berkomunikasi pada pasangan dan menimbulkan konflik keluarga (Sharaievska, Kim, \& Stodolska, 2013). Hasil penelitian Lee (2013) yang membandingkan pasangan suami-istri lintas etnis di Amerika Serikat menunjukkan ada perbedaan yang signifikan kepuasan pernikahan dilihat dari lintas-etnis. Sedangkan penelitian Cheng (2010) menunjukkan bahwa faktor etnis dan budaya mempengaruhi resolusi konflik dan kepuasan pernikahan. Hal itu juga ditemukan dalam penelitian Yelsma dan Athappilly (1988) dan Muller (2004) bahwa ada dinamika kepuasan pernikahan dan permasalahan keluarga pada beberapa pasangan beda entis dan budaya.

Berdasarkan kajian teoritis tersebut di atas dapat dipahami bahwa kepuasan pernikahan sangat dipengaruhi oleh resolusi konflik. Oleh karena itu penelitian ini menguji kembali tentang bagaimana pengaruh resolusi konflik terhadap kepuasan pernikahan. Di samping itu, berdasarkan penjelasan tersebut di atas, maka penelitian ini juga menguji perbedaan resolusi konflik dan kepuasan pernikahan ditinjau dari aspek demografi yang meliputi latar belakang etnis, tingkat pendidikan, pekerjaan, jumlah anak, lama pernikahan, status kepemilikan tempat tinggal, dan tempat tinggal bersama.

\section{Metode}

\section{Desain penelitian dan partisipan}

Penelitian ini menggunakan metode survei dengan pendekatan kuantitatif korelasional-komparatif. Subjek penelitian ini adalah pasangan suami istri yang tinggal di Kota Surabaya bagian utara dengan jumlah sampel 150 orang, yang terdiri atas 3 (tiga) etnis yaitu etnis Jawa $=50$ orang, Madura $=50$ orang, dan Arab $=50$ orang. Selanjutnya, masing-masing etnis tersebut ditetapkan secara purposive berdasarkan latar belakang (1) pendidikan terakir (SD, SMP, SMP, dan perguruan tinggi); (2) pekerjaan di bidang perdagangan, jasa, sektor swasta, sektor pemerintahan, dan mengurus rumah tangga; (3) jumlah anak minimal satu anak; (4) lama pernikahan minimal satu tahun; (5) memiliki tempat tinggal dengan status milik sendiri atau sewa; dan (6) bertempat tinggal bersama keluarga inti, orang tua/mertua, atau bersama keluarga yang lain.

\section{Instrumen penelitian}

\section{Skala Resolusi Konflik}

Skala Resolusi Konflik digunakan untuk mengukur resolusi konflik subjek penelitian. Alat ukur ini pernah dikembangkan oleh Rahmantyo (2012) dan dilakukan perbaikan dan penyesuaian sesuai dengan kondisi subjek penelitian oleh peneliti berdasarkan teori resolusi konflik dari Crawford dan Bodine, (1996) terdiri atas 28 butir mencakup 6 (enam) aspek yaitu: kemampuan orientasi, kemampuan persepsi, kemampuan emosional, kemampuan komunikasi, kemampuan berpikir kreatif, dan kemampuan berpikir kritis, dengan nilai estimasi reliabilitas Koefisien Cronbach's alpha sebesar 0.810 .

\section{ENRICH Marital Satisfaction Scale}

ENRICH Marital Satisfaction Scale digunakan untuk mengukur kepuasan pernikahan. Alat ukur ini diadaptasi dari Kusumawardani (2016) berdasarkan ENRICH Marital Satisfaction Scale yang dikembangkan oleh Fowers dan Olson (1989) terdiri atas 15 
butir mencakup 10 aspek kepuasan pernikahan yaitu: (1) isu kepribadian (personality issues); (2) pembagian peran (equalitarian roles); (3) komunikasi (communication); (4) resolusi konflik (conflict resolution); (5) manajemen keuangan (financial management); (6) aktivitas waktu luang (leisure activities); (7) orientasi seksual (sexual relationship); (8) anak dan pengasuhan (children and marriage); (9) keluarga dan teman (family and friends); dan (10) orientasi religius (religious orientation), dengan nilai estimasi reliabilitas Koefisien Cronbach's alpha sebesar 0.913.

\section{Analisis data}

Data yang telah terkumpul kemudian diolah secara kuantitatif menggunakan Program Statistical Package for Social Science (SPSS) for Windows 20.0 Version. Untuk menguji hipotesis penelitian digunakan beberapa teknik analisis statistik yaitu teknik analisis statistik deskriptif, analisis regresi (ANAREG) linier sederhana dan teknik analisis varian (ANOVA).

\section{Hasil}

Berdasarkan penelitian yang dilakukan terhadap variabel kepuasan pernikahan dan resolusi konflik maka didapat data deskriptif nilai masing-masing variabel diantara semua sampel sebagai berikut (Tabel 1):

Tabel 1

Data Deskriptif Variabel Penelitian

\begin{tabular}{lcccccc}
\hline Variabel & N & Mean & $\begin{array}{c}\text { Deviasi } \\
\text { Standar }\end{array}$ & Varians & $\begin{array}{c}\text { Nilai } \\
\text { Min. }\end{array}$ & $\begin{array}{c}\text { Nilai } \\
\text { Maks. }\end{array}$ \\
\hline $\begin{array}{l}\text { Kepuasan } \\
\text { Pernikahan }\end{array}$ & 150 & 146.09 & 20.404 & 416.33 & 99.00 & 188.00 \\
\hline $\begin{array}{l}\text { Resolusi } \\
\text { Konflik }\end{array}$ & 150 & 94.91 & 11.086 & 122.91 & 78.00 & 122.00 \\
\hline $\begin{array}{l}\text { Valid N } \\
\text { (listwise) }\end{array}$ & 150 & & & & & \\
\hline
\end{tabular}

Pada perhitungan terhadap variabel kepuasan pernikahan diperoleh mean sebesar
146.09, serta nilai standart deviation sebesar 20.40. Nilai minimum dan maksimum menunjukkan bahwa nilai paling kecil pada kepuasan pernikahan adalah 99.00 dan nilai paling besar adalah 188.00. Berdasarkan hasil perhitungan terhadap variabel resolusi konflik diperoleh mean sebesar 94.91, serta nilai standart deviation sebesar 11.09. Nilai minimum dan maksimum menunjukkan bahwa nilai paling kecil pada resolusi konflik adalah 78.00 dan nilai paling besar adalah 122.00 .

Sebelum data dianalisis menggunakan analisis statistik inferensial yaitu analisis regresi (ANAREG) linier sederhana, maka perlu dilakukan uji asumsi/prasyarat yaitu uji normalitas data masing-masing data variabel resolusi konflik dan kepuasan pernikahan. Hasil uji normalitas data menggunakan OneSample Kolmogorov-Smirnov Test pada variabel resolusi konflik diperoleh harga $p=0.715>0.05$ dan variabel kepuasan pernikahan diperoleh harga $p=0.687>0.05$, artinya kedua data variabel resolusi konflik dan kepuasan pernikahan ini berdistribusi normal. Hasil analisis regresi (ANAREG) linier sederhana dijelasakan pada Tabel 2.

Tabel 2

Nilai Koefisien Korelasi dan Determinasi

\begin{tabular}{cccccc}
\hline Model & $\mathbf{R}$ & $\begin{array}{c}\mathbf{R} \\
\text { Square }\end{array}$ & $\begin{array}{c}\text { Adjusted } \\
\mathbf{R} \\
\text { Square }\end{array}$ & $\begin{array}{c}\text { Estimasi } \\
\text { Std. } \\
\text { Error }\end{array}$ & $\begin{array}{c}\text { Durbin- } \\
\text { Watson }\end{array}$ \\
\hline 1 & $.659^{\mathrm{a}}$ & .434 & .430 & 15.40487 & 1.524 \\
\hline
\end{tabular}

a. Prediktor: (Konstan), Resolusi Konflik

b. Variabel Dependen: Kepuasan Pernikahan

Nilai koefisien korelasi $\mathrm{R}=0.659$ menunjukkan adaanya korelasi antara resolusi konflik dengan kepuasan pernikahan dengan nilai koefisien determinasi R Square $=0.434$. Angka tersebut berarti terdapat $43 \%$ pengaruh resolusi konflik terhadap kepuasan 
pernikahan, sedangkan sisanya $57 \%$ harus dijelaskan oleh faktor-faktor penyebab lainnya.

Tabel 3

Perhitungan ANOVA

\begin{tabular}{ccccccc}
\hline Model & $\begin{array}{l}\text { Sum of } \\
\text { Square }\end{array}$ & Df & $\begin{array}{l}\text { Rata- } \\
\text { rata } \\
\text { Square }\end{array}$ & F & Sig. \\
\hline 1 & Regression & 26910.80 & 1 & 26910.80 & 113.40 & $.000^{\mathrm{a}}$ \\
\hline & Residual & 35121.90 & 148 & 237.31 & & \\
\hline & Total & 62032.70 & 149 & & &
\end{tabular}

a. Prediktor: (Konstan), Resolusi Konflik

b. Variabel Dependen: Kepuasan Pernikahan

Pada Tabel 3 hasil perhitungan ANOVA menunjukkan harga $\mathrm{F}=113.399 \quad$ Nilai $p=0.000<0.05$ artinya terdapat pengaruh yang signifikan antara resolusi konflik terhadap kepuasan pernikahan.

Tabel 4

Hasil Analisis Regresi

\begin{tabular}{ccccccc}
\hline $\begin{array}{c}\text { Mo } \\
\text { del }\end{array}$ & & Unstand. Coeff. & $\begin{array}{l}\text { Stand. } \\
\text { Coeff. }\end{array}$ & & \\
\hline & & B & $\begin{array}{c}\text { Std. } \\
\text { Error }\end{array}$ & Beta & t & Sig. \\
\hline 1 & (Konstan) & 31.044 & 10.877 & & 2.85 & .005 \\
\hline & $\begin{array}{c}\text { Resolusi } \\
\text { Konflik }\end{array}$ & 1.212 & .114 & .659 & 10.65 & .000
\end{tabular}

a. Variabel Dependen: Kepuasan Pernikahan

Berdasarkan Tabel 4 dapat dijelaskan bahwa ada pengaruh yang signifikan resolusi konflik terhadap kepuasan pernikahan, dengan nilai $\mathrm{t}=10.649$ dan nilai $p=0.000<0.05$, artinya variabel resolusi konflik secara signifikan mampu memprediksi kepuasan pernikahan.

Berdasarkan data hasil penelitian dari 150 subjek penelitian menunjukkan bahwa hipotesis yang diajukan diterima, yang berarti bahwa terdapat hubungan positif yang signifikan antara resolusi konflik dengan kepuasan pernikahan. Berdasarkan uji analisis regresi linier sederhana diperoleh koefisien korelasi dengan $\mathrm{F}=113.399$ dan $p=0.000<0.05$, dengan koefisien determinasi sebesar 0.434 atau $43 \%$ yang artinya ada pengaruh antara resolusi konflik terhadap kepuasan pernikahan cukup besar dan signifikan, yakni $43 \%$ dan $57 \%$ dipengaruhi oleh faktor lain.

\section{Diskusi}

Hasil penelitian ini sejalan dengan teori dari McDaniel (2000) yang menyatakan bahwa seberapa baik pasangan menangani stresor dan menyelesaikan konflik akan berpengaruh pada kepuasan pernikahannya. Senada pula dengan teori dari Strong dan Cohen (2011) yang menyatakan bahwa penyelesaian konflik antar pasangan dalam pernikahannya merupakan salah satu faktor yang paling penting dalam menentukan kepuasan dan kesejahteraan hubungannya.

Indikator utama pada penyelesaian konflik pernikahan yang konstruktif tampak pada kepuasan pasangan serta perasaan mereka terhadap hubungan yang terjalin. Untuk mempertahankan pernikahan, pasangan perlu memperhatikan kemampuannya dalam menghadapi konflik. Jika konflik dapat dikelola secara konstruktif, maka pernikahan akan bertahan dengan baik. Sebaliknya, jika konflik dihadapi secara destruktif oleh pasangan, maka mereka relatif merasa tidak puas dalam hubungan pernikahannya (Greef \& Bruyne, 2000). Resolusi konflik memang berkaitan dengan kepuasan pernikahan dan menjadi salah satu bagian penting dalam mencapai kesejahteraan psikologis pasangan dalam kehidupan pernikahan. Kemampuan pasangan dalam menghadapi konflik dan menyelesaikannya juga dipengaruhi oleh persepsinya terhadap pernikahan yang dibangun. Apapun gaya serta teknik penyelesaian konflik yang dipilih, perlu dipertimbangkan efektifitasnya dalam 
mencapai kepuasan pernikahan. Di samping itu, kemauan pasangan untuk mencari upaya penyelesaian konflik yang sesuai juga menjadi salah satu pertimbangan dalam meraih pernikahan yang bahagia.

Kepuasan pernikahan merupakan aspek dalam kualitas pernikahan yang memainkan peran penting dalam kehidupan rumah tangga. Tidak dapat dipungkiri bahwa kepuasan pernikahan muncul seiring dengan kebutuhan untuk mengidentifikasi karakter, pola komunikasi dan perilaku adaptif pasangan. Terlebih lagi, menurut Ahmadi dan HosseinAbdi (2009) kepuasan pernikahan telah terbukti efektif menyebabkan peningkatan pada semua aspek kehidupan, termasuk fungsi keluarga, peran sebagai orang tua, kesehatan sampai pada kepuasan hidup. Dengan demikian, kepuasan pernikahan menjadi faktor esensial dalam kesehatan mental individu maupun keluarga.

Hasil penelitian ini memiliki kesamaan dengan penelitian-penelitian sebelumnya tentang hubungan resolusi konflik dengan kepuasan pernikahan. Penelitian sebelumnya dilakukan oleh Askari, Noah, Hassan, dan Baba (2012) tentang pengaruh pelatihan komunikasi dan resolusi konflik pada kepuasan pernikahan di Malaysia. Hasil penelitiannya mengindikasikan bahwa pelatihan komunikasi dan resolusi konflik efektif meningkatkan kepuasan pernikahan. Selanjutnya, Ahangar, Juhari, Yacoob, dan Talib (2014) meneliti tentang peran gender terhadap hubungan resolusi konflik dan kepuasan pernikahan pada mahasiswa yang telah menikah dengan subjek mahasiswa pasca sarjana Universitas Terbuka Malaysia di Kuala Lumpur. Hasil penelitian mengindikasikan bahwa resolusi konflik berhubungan positif dengan kepuasan pernikahan. Subjek yang memiliki kemampuan resolusi konflik yang baik memiliki tingkat kepuasan pernikahan yang tinggi pula. Stinson, Bermudez, Gale, Lewis, Meyer, dan Templeton, (2017) juga melakukan penelitian tentang kepuasan pernikahan, gaya resolusi konflik dan kehadiran agama terhadap 191 pasangan Latin di Amerika. Hasil penelitian menunjukkan berbagai gaya resolusi konflik pasangan mempengaruhi kepuasan pernikahan.

Penelitian ini juga didukung oleh beberapa data demografi untuk menjabarkan lebih rinci keadaan subjek penelitian yang kaitannya dengan resolusi konflik dan kepuasan pernikahan. Peneliti mencantumkan data demografi seperti latar belakang suku/etnis, tingkat pendidikan, pekerjaan, jumlah anak yang dimiliki, lama pernikahan, status kepemilikan tempat tinggal, dan bertempat tinggal bersama siapa saja subjek penelitian. Hasil analaisis uji perbandingan untuk menguji perbedaan resolusi konflik dan kepuasan pernikahan ditinjau dari aspek demografi menunjukkan bahwa terdapat perbedaan tingkat resolusi konflik dan kepuasan pernikahan antara etnis Jawa, Madura, dan Arab. Subjek yang berlatar belakang etnis Arab memiliki tingkat kepuasan pernikahan tertinggi. Sedangkan untuk tingkat tertinggi resolusi konflik juga terdapat pada subjek dengan latar belakang etnis Arab. Hal ini berkaitan dengan status sosial keluarga sebagaimana teori dari Blood dan Wolfe (1969) yang menyebut latar belakang etnis yang sama juga mempengaruhi kepuasan pernikahan yang didapat.

Berdasarkan tingkat pendidikan, terdapat perbedaan tingkat kepuasan pernikahan dan resolusi konflik antara subjek yang memiliki tingkat pendidikan SD, SMP, SMA, dan perguruan tinggi. Kepuasan 
pernikahan dan resolusi konflik tertinggi terdapat pada subjek yang memiliki pendidikan terakhir tingkat SD. Hal ini berkaitan dengan tuntutan yang dimiliki oleh pasangan berdasarkan tingkat pendidikannya. Pasangan yang memiliki tingkat pendidikan tinggi cenderung memiliki tuntutan atau ekspektasi yang lebih tinggi pula dibandingkan pasangan yang tingkat pendidikannya lebih rendah. Meskipun penelitian ini menunjukkan adanya perbedaan kepuasan pernikahan antara subjek yang berbeda latar belakang pendidikan, namun untuk menentukan siapa yang memiliki tingkat kepuasan tertinggi belum dapat dipastikan karena penelitian lain menunjukkan hasil yang berbeda. Sehingga penelitian kepuasan pernikahan berdasarkan pendidikan ini menarik untuk diteliti lebih lanjut.

Data demografi berikutnya adalah jenis pekerjaan. Hasil penelitian menunjukkan bahwa terdapat perbedaan yang signifikan terkait resolusi konflik dan kepuasan pernikahan antara subjek yang bekerja di bidang perdagangan, jasa, swasta, PNS (Pegawai Negeri Sipil) dan IRT (Ibu Rumah Tangga). Dalam penelitian ini, subjek yang bekerja di bidang perdagangan memiliki tingkat kepuasan pernikahan tertinggi. Sedangkan resolusi konflik tertinggi terdapat pada pekerjaan sebagai ibu rumah tangga. Hal ini mungkin terjadi karena ibu rumah tangga lebih sedikit mengalami konflik kerja-keluarga atau peran ganda dibanding istri yang bekerja (Handayani \& Harsanti, 2017).

Berdasarkan jumlah anak yang dimiliki pasangan, penelitian ini menunjukkan bahwa terdapat perbedaan kepuasan pernikahan dan resolusi konflik antara subjek yang memiliki anak antara satu sampai dua, tiga sampai empat, dan lebih dari empat. Pasangan yang memiliki jumlah anak lebih dari empat menunjukkan tingkat kepuasan pernikahan dan resolusi konflik tertinggi. Sebagaimana hasil penelitian Levenson, Carstensen, dan Gottman, (1993) yang menunjukkan bahwa jumlah anak mempengaruhi konflik dan kepuasan pernikahan. Hal itu sejalan dengan pernyataan Hurlock (2002) yang berpendapat bahwa lebih banyak perceraian terjadi karena pasangan tidak mempunyai anak. Jumlah anak yang banyak cenderung membuat orang tua tenang karena anak dianggap sebagai investasi yang kelak bisa membatu pekerjaan orang tua. Sebaliknya, jika pasangan suami-istri tidak memiliki anak cenderung sedih, merasa kesepian, tidak nyaman, mengalami kejenuhan dalam pernikahan dan rentan konflik rumah tangga (Mardiyan, \& Kustanti, 2016).

Berkaitan dengan lamanya waktu menikah, penelitian ini menunjukkan bahwa terdapat perbedaan kepuasan pernikahan dan resolusi konflik pada pasangan yang usia pernikahannya antara satu sampai lima tahun, enam sampai sepuluh tahun, sebelas sampai lima belas tahun, dan lebih dari lima belas tahun (Mirecki, Chou, Elliott, \& Schneider (2013). Pasangan yang menikah lebih dari 15 tahun memiliki kepuasan pernikahan dan resolusi konflik tertinggi. Pasangan yang usia pernikahan lebih lama secara psikologis matang dalam rumah tangga dan lebih mudah menyelesaikan konflik dan mendapatkan kepuasan pernikahan yang terjamin (Levenson, Carstensen, \& Gottman, (1993). Hal ini sesuai juga dengan pernyataan Hurlock (2002), pada tahun pertama dan kedua pernikahan, pasangan suami istri biasanya harus melakukan penyesuaian diri baik terhadap pasangan, keluarga pasangan, maupun teman-teman pasangan. Keadaan ini sering menimbulkan ketegangan emosional dan menjadi salah satu pemicu menurunnya 
kepuasan pernikahan di tahun-tahun awal. Oleh karena itu kestabilan emosi dan keberagamaan turut menjaga keharmonisan kepuasan keluarga dan menghindari konflik rumah tangga (Khalatbari, Ghorbanshiroudi, Azari, Bazleh, \& Safaryazdi, 2013).

Hasil penelitian ini juga diketahui bahwa pasangan yang bertempat tinggal di rumah yang berstatus miliki sendiri merasakan kepuasan pernikahan yang lebih tinggi dibanding dengan pasangan yang tinggal di rumah berstatus sewa. Selain itu, terdapat perbedaan resolusi konflik dan kepuasan pernikahan antara pasangan yang tinggal dengan keluarga inti, orang tua/mertua dan saudara yang lain. Pasangan yang bertempat tinggal bersama keluarga inti memiliki tingkat kepuasan pernikahan tertinggi sedangkan pasangan yang tinggal bersama orang tua/mertua memiliki kepuasan pernikahan terendah. Hal ini selaras dengan hasil penelitian yang dilakukan oleh Saputra, Hartati, dan Aviani (2014) yang menyatakan adanya perbedaan kepuasan pernikahan antara pasangan yang tinggal bersama atau terpisah dari orang tua/mertua. Pasangan yang tinggal terpisah dari orang tua/mertua lebih puas terhadap pernikahannya karena membuat mereka lebih nyaman dan tenang sebagai pasangan suami istri dan merasa lebih bahagia sebab apa yang mereka raih adalah atas jerih payah mereka berdua, bukan pemberian orang tua/mertua. Segala bentuk masalah pun dapat mereka selesaikan berdua tanpa campur tangan orang tua/mertua.

Berdasarkan hasil penelitian ini, maka dapat disimpulkan bahwa ada pengaruh yang signifikan antara resolusi konflik terhadap kepuasan pernikahan. Penelitian ini menunjukkan bahwa ada hubungan positif yang signifikan antara resolusi konflik dengan kepuasan pernikahan, semakin tinggi pasangan mampu menyelesaikan konflik maka semakin tinggi kepuasan pernikahan, dan sebaliknya. Hasil penelitian ini juga membuktikan kembali bahwa resolusi konflik dapat memprediksi tingkat kepuasan pernikahan. Hasil penelitian lainnya menunjukkan bahwa terdapat perbedaan yang signifikan resolusi konflik dan kepuasan pernikahan ditinjau dari aspek demografi meliputi latar belakang etnis, tingkat pendidikan, pekerjaan, jumlah anak, lama pernikahan, status kepemilikan tempat tinggal, dan tempat tinggal bersama.

\section{Daftar Pustaka}

Ahangar, K., Juhari, R., Yacoob, S., \& Talib, M. (2014). Moderating Effect of Gender Role on the Association between Conflict Resolution and Marital Satisfaction of Iranian Married Student. International Journal of Humanities Social Sciences and Education (IJHSSE), 1(12), 141-146. Diambil dari: https://www.arcjournals.org/pdfs/ijhsse/ v1-i12/18.pdf

Ahmadi, K., \& Hossein-Abadi, F. H. (2009). Religiosity, marital satisfaction and child rearing. Pastoral Psychology, 57(5-6), 211-221. doi: https://doi.org/10.1007/s11089-008$\underline{0176-4}$

Askari, M., Noah, S., Hassan, S., \& Baba, M. (2012). Comparison the Effect of Communication and Conflict Resolution Skills Training on Marital Satisfaction. International Journal of Psychological Studies, 4(1), 182-195. doi: https://doi.org/10.5539/ijps.v4n1p182

Badan Pusat Statistik. (2016). Kemajuan yang Tertunda: Analisis Data Perkawinan 
Usia Anak di Indonesia. Jakarta: Badan Pusat Statistik.

Blood, R. O., \& Wolfe, D. M. (1969). Negrowhite differences in blue-collar marriages in a northern metropolis. Social Forces, 48(1), 59-64. doi: https://doi.org/10.1093/sf/48.1.59

Burpee, L. C., \& Langer, E. J. (2005). Mindfulness and marital satisfaction. Journal of Adult Development, 12(1), 43-51. doi: https://doi.org/10.1007/s10804-005$\underline{1281-6}$

Cheng, C. C. (2010). A study of inter-cultural marital conflict and satisfaction in Taiwan. International Journal of Intercultural Relations, 34(4), 354-362. doi:

https://doi.org/10.1016/j.ijintrel.2010.04 $\underline{.005}$

Crawford, D., \& Bodine, R. (1996). Conflict Resolution Education Program Report. Washington, DC: U.S. Department of Justice.

Dariyo, A. (2004). Memahami psikologi perceraian dalam kehidupan keluarga. Jurnal Psikologi, 2(2), 94-100. Diambil dari:

https://digilib.esaunggul.ac.id/public/U EU-Journal-4955-Agoes\%20Dariyo.pdf

Dewi, E. M. P., \& Saman, A. (2018). Peran Motivasi Kerja dan Dukungan Suami Terhadap Stres Konflik Peran Ganda dan Kepuasan Perkawinan. Psympathic: Jurnal Ilmiah Psikologi, 3(2), 167. doi: https://doi.org/10.15575/psy.v3i2.2185.

Dwyer, M. T. (2005). Emotional intelligence and conflict resolution style as predictors of marital satisfaction in the first year of marriage. Dissertation Abstracts International: Section B: The Sciences and Engineering.

stephan, A. S. (2007). The relationship between marital humility, marital communication, and marital satisfaction. Dissertation Abstracts International Section A: Humanities and Social Sciences, 68(6-A), 2334.

Fowers, B. J., \& Olson, D. H. (1993). ENRICH Marital Satisfaction Scale: A brief research and clinical tool. Journal of Family Psychology, 7(2), 176-185. doi: http://dx.doi.org/10.1037/0893$\underline{3200.7 .2 .176}$

Giblin, P. (1994). Marital Satisfaction. The Family Journal. doi: https://doi.org/10.1177/1066480794021 $\underline{008}$

Goei, Y. A. (2017). Jebakan Dalam Memilih Pasangan Hidup. Jurnal Psikologi Ulayat, 2(2), 412-419. doi: https://doi.org/10.24854/jpu22015-36

Greeff, A. P., \& de Bruyne, T. A. (2000). Conflict management style and marital satisfaction. Journal of Sex and Marital Therapy, 26(4), 321-334. doi: https://doi.org/10.1080/0092623004387 $\underline{24}$

Handayani, Y. (2016). Komitmen, Conflict Resolution, dan Kepuasan Perkawinan Pada Istri yang Menjalani Hubungan Pernikahan Jarak Jauh (Karyawan Schlumberger Balikpapan). Psikoborneo, 4(3), 518-529.

Handayani, N. S., \& Harsanti, I. (2017). Kepuasan Pernikahan: Studi Pengaruh Konflik Pekerjan-Keluarga pada Wanita Bekerja. Jurnal Ilmiah Psikologi, 10(1), 
92-99. doi: http://dx.doi.org/10.35760/psi.2017.v10 i1.1638

Hanzal, A., \& Segrin, C. (2009). The Role of Conflict Resolution Styles in Mediating the Relationship Between Enduring Vulnerabilities and Marital Quality. Journal of Family Communication, 9(3), 150-169.

doi: https://doi.org/10.1080/1526743090294 $\underline{5612}$

Herawati, I., \& Farradinna, S. (2017). Kepuasan perkawinan ditinjau dari kebersyukuran dan pemaafan pada pasangan bekerja. Mediapsi, 3(2), 10-21. doi:

https://doi.org/10.21776/ub.mps.2017.0 03.02.2

Hurlock, E. (2002). Psikologi Perkembangan: Suatu Pendekatan Sepanjang Rentang Kehidupan. Jakarta: Erlangga.

Istiqomah, I., \& Mukhlis, M. (2015). Hubungan Antara Religiusitas dengan Kepuasan Perkawinan. Jurnal Psikologi UIN Sultan Syarif Kasim Riau, 11(2), 71-78. doi: http://dx.doi.org/10.24014/jp.v11i2.139 $\underline{6}$

Jawa Pos. (2017, Agustus). Setahun 4938 Perceraian. Diakses dari https://www.pressreader.com/indonesia/ jawa-pos/20170801/282432759232713

Kaur, T., \& Sokhey, G. (2010). Conflict resolution and marital satisfaction. Indian Journal of Community Psychology, 6(1), 90-104.

Khalatbari, J., Ghorbanshiroudi, S., Azari, K. N., Bazleh, N., \& Safaryazdi, N. (2013). The Relationship between Marital
Satisfaction (Based on Religious Criteria) and Emotional Stability. Procedia Social and Behavioral Sciences, 84, 869-873. doi: https://doi.org/10.1016/j.sbspro.2013.06 .664

Kurdek, L. A. (1995). Predicting Change in Marital Satisfaction from Husbands' and Wives' Conflict Resolution Styles. Journal of Marriage and the Family, 57(1), 153.

Doi: https://doi.org/10.2307/353824

Kusumawardani, N. R. W. (2016). Perbedaan Kepuasan Pernikahan Suami Ditinjau dari Status Istri. Skripsi. Malang: Fakultas Psikologi Universitas Muhammadiyah Malang.

Lee, S. (2013). Comparing Marital Satisfaction, Acculturation, and Personality across Asian-Mixed Couples and Asian Couples in the United States. Dissertation. Corpus Christi: Texas A\&M University.

Levenson, R. W., Carstensen, L. L., \& Gottman, J. M. (1993). Long-Term Marriage: Age, Gender, and Satisfaction. Psychology and Aging, 8(2), 301-313. doi: $\quad$ https://doi.org/10.1037/08827974.8.2.301

Marchand, J. F., \& Hock, E. (2000). Avoidance and attacking conflictresolution strategies among married couples: Relations to depressive symptoms and marita satisfaction. Family Relations, 49(2), 201-206. doi: https://doi.org/10.1111/j.17413729.2000.00201.x

Mardiyan, R., \& Kustanti, E. R. (2016). Kepuasan Pernikahan pada Pasangan yang Belum Memiliki Keturunan. Jurnal 
Empati, 5(3), 558-565.

McDaniel, S. (2000). Close Relations; An Introduction to The Sociology of Families. Toronto: Prentice-Hall Canada Inc.

Mirecki, R. M., Chou, J. L., Elliott, M., \& Schneider, C. M. (2013). What Factors Influence Marital Satisfaction? Differences Between First and Second Marriages. Journal of Divorce and Remarriage, 54(1), 78-93. doi: https://doi.org/10.1080/10502556.2012. 743831

Muller, R. D. (2004). Relationship dynamics in Latino-White intercultural marriages: A three group comparison. Dissertation Abstracts International: Section B: The Sciences and Engineering.

Munoz, S. (2011). The Relationship Among Gratitude, Forgiveness, Conflict Resolution, Duration of Marriage and Marital Satisfaction. ProQuest Dissertations and Theses.

Nurilah, D. (2016). Di Indonesia, puluhan kasus perceraian terjadi setiap jam. Diambil dari: https://www.liputan6.com/news/read/26 58483/di-indonesia-puluhan-kasusperceraian-terjadi-setiap-jam

Olson, D., \& DeFrain, J. (2006). Marriage and Families: Intimacy, Diversity, and Strenght 5th Edition. New York: McGraw-Hill.

Orathinkal, J., \& Vansteenwegen, A. (2006). Religiosity and marital satisfaction. Contemporary Family Therapy, 28(4), 497-504. doi: https://doi.org/10.1007/s10591-006$\underline{9020-0}$
Papalia, D., Old, S., \& Feldman, R. (2008). Human Development (Psikologi Perkembangan) Edisi Kesembilan. Jakarta: Kencana Prenada Media Group.

Prasetyo, K. B., \& Rahmasari, D. (2016). Hubungan Antara Dukungan Sosial Keluarga dengan Kepuasan Perkawinan Pada Istri. Jurnal Penelitian Psikologi, 7(1), 1-10.

Rahmantyo, T. (2012). Upaya Peningkatan Kemampuan Resolusi Konflik Melalui Bimbingan Kelompok Bagi Siswa Kelas $X$ - Logam SMK Negeri 1 Kalasan. Yogyakarta: Fakultas Ilmu Pendidikan Universitas Negeri Yogyakarta.

Ragoan, S., Untoro, V., \& Ari, D. R. (2017). Gambaran kepuasan pernikahan pada wanita keturunan Arab yang melakukan pernikahan dengan etnis lain. Jurnal Psikologi Ulayat, 4(2), 107. doi: https://doi.org/10.24854/jpu22017-99

Rini, Q. K., \& Retnaningsih. (2008). Keterbukaan Diri dan Kepuasan Perkawinan pada Pria Dewasa Awal. Jurnal Ilmiah Psikologi, 1(2), 152-157. doi:

http://dx.doi.org/10.35760/psi.2008.v1i $\underline{2.293}$

Rumondor, P. C. (2013). Pengembangan alat ukur kepuasan pernikahan pasangan urban. Humaniora, 4(2), 1134-1140.

Rumondor, P. C. B., Paramita, G. V., Francis, N. P., \& Geni, P. L. (2013). Dampak Penghasilan Istri pada Kepuasan Pernikahan Dewasa. Jurnal Psikologi Ulayat, 1(2). doi: https://doi.org/10.24854/jpu22013-20

Sadarjoen, S. (2005). Konflik Marital: Pemahaman Konseptual, Aktual dan 
Alternatif Solusinya. Bandung: Refika Aditama.

Sakuei, S. (2014). Marital satisfaction and conflict resolution in first generation Iranian Americans. Dissertation Abstracts International: Section B: The Sciences and Engineering.

Saputra, F., Hartati, N., \& Aviani, Y. I. (2014). Perbedaan Kepuasan Pernikahan Antara Pasutri yang Serumah dan Terpisah dari Orangtua/Mertua. Jurnal RAP UNP, 5(2), 136-245. doi: https://doi.org/10.24036/rapun.v5i2.662 $\underline{8}$

Sawitri, S. A., \& Kurniawan, I. N. (2009). Fleksibilitas pasangan dan kepuasan perkawinan. Psikologika: Jurnal Pemikiran dan Penelitian Psikologi, 14(1), 81-89. doi: https://doi.org/10.20885/psikologika.vol 14.iss1.art8

Sharaievska, I., Kim, J., \& Stodolska, M. (2013). Leisure and Marital Satisfaction in Intercultural Marriages. Journal of Leisure Research, 45(4), 445-465. doi: https://doi.org/10.18666/jlr-2013-v45i4-3894

Srisusanti, S., \& Zulkaida, A. (2013). Studi deskriptif mengenai faktor-faktor yang mempengaruhi kepuasan perkawinan pada istri. UG Jurnal, 7(6), 133-141.

Stinson, M., Bermudez, J., Gale, J., Lewis, D., Meyer, A., \& Templeton, G. (2017). Marital Satisfaction, Conflict Resolution Style, and Religion Attendance Among Latino Couple: Using the Actor-Partner Interdependence Model. The Family Journal, 25(3)215-223. doi: https://doi.org/10.1177/1066480717710 $\underline{645}$
Strong, B., \& Cohen, T. (2011). The Marriage and Family Experience: Intimate Relationship in a Changing Society, 12th Edition. Boston, MA: Cengeage Learning.

Sudarto, A. (2014). Studi Deskriptif Kepuasan Perkawinan pada Perempuan yang Menikah Dini. Calyptra: Jurnal Ilmiah Mahasiswa Universitas Surabaya, 3(1), 1-15.

Surya, T. F. (2013). Kepuasan Perkawinan pada Istri Ditinjau dari Tempat Tinggal. Calyptra: Jurnal Ilmiah Mahasiswa Universitas Surabaya, 2(1), 1-13.

Utami, T., \& Mariyati, L. I. (2015). Persepsi terhadap Resolusi Konflik Suami dan Kepuasan Pernikahan pada Istri Bekerja di Kelurahan Bligo. Prosiding Seminar Psikologi dan Kemanusiaan, hal. 407414.

Yelsma, P., \& Athappilly, K. (1988). Marital Satisfaction and Communication Practices: Comparisons among Indian and American Couples. Journal of Comparative Family Studies, 19(1), 3754. doi: https://doi.org/10.2307/41601406

Ziv, A., \& Gadish, O. (1989). Humor and marital satisfaction. Journal of Social Psychology, 129(6), 759-768. doi: https://doi.org/10.1080/00224545.1989. $\underline{9712084}$ 